\title{
Rigidoporus crocatus re-collected in Finland plus new records of other rare polypores (Basidiomycetes)
}

\author{
PERTTIRENVALL and KAISA JUNNINEN
}

\begin{abstract}
RENVALL, P. \& JUNNINEN, K. 1999: Rigidoporus crocatus re-collected in Finland plus new records of other rare polypores (Basidiomycetes). - Karstenia 39:33-35. Helsinki. ISSN 0453-3402

Oligoporus folliculocystidiatus Kotl. \& Vampola, O. lowei (Pilát) Gilb. \& Ryvarden, Piloporia sajanensis (Parmasto) Niemelä, Rigidoporus crocatus (Pat.) Ryvarden and some other rare polypores (Basidiomycetes) are reported from the old-growth forests of eastern Finland. The collection of $R$. crocatus is the first in this century from the country. The species was considered to be extinct until the present find from Ilomantsi.
\end{abstract}

Key words: Betula, old-growth forest, Rigidoporus crocatus, threatened fungi

Pertti Renvall, Kuopio Natural History Museum, Myhkyrinkatu 22, FIN-70100 Kuopio,Finland,email: pertti.renvall@kuopio.fi

Kaisa Junninen, Department of Biology, University of Joensuu, P.O. Box 111, FIN80101 Joensuu, Finland

\section{Introduction}

The old-growth forests of eastern Finland have recently attracted the attention of many conservationists, ecologists and mycologists. Woodrotting fungi, especially polypores, are fairly well known in the area and some regional species lists (Kotiranta et al. 1994, Penttilä 1994, Anttila et al. 1995, Junninen 1996, Kotiranta \& Niemelä 1996, Bondartseva et al., 1998, Renvall 1998, Lindgren 1999, Vehmaa 1999) are already available. Active collecting by forest conservationists has rapidly increased the distributional data of these fungi, and during the last five years plenty of new records of, e.g., rare and threatened polypores have been made. The present paper reports the most recent of them from the municipalities of Suomussalmi, Kuhmo and Ilomantsi in eastern Finland.
The material treated here was collected by Kaisa Junninen (KJ) during old-growth forest inventories in 1998. The specimens were identified and the text was written by PR. For a description of the microscopical examination see Renvall (1992). Voucher specimens are deposited in the Kuopio Natural History Museum (KUO). All the localities given below are previously unstudied and therefore not included in the work of Kotiranta and Niemelä (1996). The co-ordinates are given according to the Finnish national uniform grid system $\left(27^{\circ} \mathrm{E}\right)$.

\section{Results}

Amyloporia crassa (P. Karst.) Bondartsev \& Singer

Specimens examined: Kainuu, Suomussalmi, Hossa, Moilasenvaara, 72626: 6046 (KJ 953); 72631: 6044 (KJ 927); 72649: 6061 (KJ 1048). 
Amyloporia crassa has been classified as threatened in Finland (vulnerable), Norway (endangered) and Sweden (endangered) (see Kotiranta \& Niemelä 1996). The present three collections are from fallen, extensively decayed trunks of pine (Pinus sylvestris).

\section{Antrodia infirma Renvall \& Niemelä}

Specimens examined: Kainuu, Suomussalmi, Hossa, Moilasenvaara, 72655: 6045 (KJ 940); 72656: 6047 (KJ 944).

Both finds are from large, fallen, extensively decayed pine trunks. The species has been classified as threatened in Finland (rare) and in Sweden (vulnerable).

Antrodia mellita Niemelä \& Penttilä

Specimens examined: Kainuu, Kuhmo, Laamasenvaara, 70978: 6591 (KJ 808a); 70984: 6594 (KJ 827a).

The collections derive from fallen, strongly decayed trunks of Populus tremula. Antrodia mellita has been classified as threatened (vulnerable) in Finland. A. pulvinascens (Pilát) Niemelä ( $K J$ 808b, 827b), another threatened (care demanding) polypore, was also found on the same trunks.

Antrodiella citrinella Niemelä \& Ryvarden Specimens examined: Kainuu, Kuhmo, Laamasenvaara, 70966: 6616 (KJ 912); 70968: 6617 (KJ 903). Suomussalmi, Hossa, Moilasenvaara, 72647: 6042 (KJ 1069).

Three collections from strongly decayed spruce (Picea abies) trunks. In Finland Antrodiella citrinella grows almost exclusively on trunks of spruce previously decayed by Fomitopsis pinicola (Sw. : Fr.) P. Karst. Old basidiocarps of the latter were found on two of the trunks. A. citrinella has been classified as threatened (vulnerable) in Finland and in Norway.

Diplomitoporus crustulinus (Bres.) Domański Specimen examined: Kainuu, Suomussalmi, Hossa, Moilasenvaara, 72655: 6073 (KJ 1015).

A rare polypore of spruce-dominated old-growth forests. Classified as threatened (vulnerable) in Finland, Norway and Sweden.

Oligoporus folliculocystidiatus Kotl. \& Vampola
Specimen examined: Pohjois-Karjala, Ilomantsi, Lakonjärvi 69983: 7178 (KJ 1115).

This newly described (Kotlaba \& Vampola 1993) and most probably very rare species was recently reported from Finland by Niemelä (1997). The present collection from fallen spruce is the second from the country.

Oligoporus lowei (Pilát) Gilb. \& Ryvarden

Specimen examined: Kainuu, Suomussalmi, Hossa, Moilasenvaara 72647: 6060 (KJ 1042).

The collection derives from a big, fallen and strongly decayed trunk of pine. Previously Oligoporus lowei (sensu typi, see Renvall 1992) has been recorded only three times from Finland (Niemelä 1997, Renvall 1998).

\section{Piloporia sajanensis (Parmasto) Niemelä}

Specimens examined: Kainuu, Suomussalmi, Hossa, Moilasenvaara 72648: 6050 (KJ 1072); 72648: 6068 (KJ 1045); 72650: 6083 (KJ 986); 72653: 6058 (KJ 1031).

This boreo-continental rarity has been classified as threatened in Finland (vulnerable) and in Sweden (endangered). In Fennoscandia it grows almost exclusively on fallen spruce trunks decayed by Trichaptum laricinum (P. Karst.) Ryvarden (Niemelä et al. 1995). In addition to the four collections cited above one observation (72650: 6083) was made. All of them derive from fallen spruce trunks extensively decayed by $T$. laricinum.

Rigidoporus crocatus (Pat.) Ryvarden

Specimen examined: Pohjois-Karjala, Ilomantsi, Tapionaho, Betula, 69817(-8): 7282-4, 8.X.1998 KJ 1077a.

This is the first Finnish record of Rigidoporus crocatus in this century. Previously only two, over 100 years old collections (Satakunta, Merikarvia, 1859; Etelä-Häme, Tammela, end of the 19 th century) were known, and the species was considered to be extinct (Kotiranta \& Niemelä 1996). $R$. crocatus has not been recorded in the other Nordic countries (Vesterholt 1997) but there are some recent collections from the Karelian Republic, Russia (R. Penttilä, pers. comm.) and from Estonia (T. Niemelä, pers. comm.)

The species was found on a fallen trunk of Betula in a moist old-growth forest. The site is situated on a gentle northern slope predominated by 
spruce. Other abundant tree species were Betula sp. and Populus tremula. The forest is characterized by big old trees and a large amount of decaying wood. The area belongs to the planned Koitajoki Nature Reserve, and it is also known for its rich Coleopteran fauna (Yakovlev et al. 1995).

\section{References}

Anttila, S., Uimonen, J. \& Vehmaa, P. 1995: Käävät aarniometsien ilmentäjinä Kainuun kuusikoissa. - Lutukka 11:42-48.

Bondartseva, M.A., Lositskaya, V.M. \& Zmitrovich, I.V. 1998: Aphyllophoroid fungi of old and primeval forests in the Kotavaara site of North Karelian Biosphere Reserve. - Folia Cryptog. Estonica 33:19-24.

Junninen, K. 1996: Kääpälajisto talous- ja aarniometsissä Ilomantsissa. 35 pp. - Unpubl. M. Sc. thesis, Dept. Biol., Univ. Joensuu.

Kotiranta, H. \& Niemelä, T. 1996: Uhanalaiset käävät Suomessa. Threatened polypores in Finland. 2nd ed. Suomen ympäristökeskus \& Edita, Helsinki, 184 pp.

Kotiranta, H., Niemelä, T. \& Penttilä, P. 1994: Talaskankaan-Sopenmäen vanhojen metsien suojeluarvo lahottajasienilajiston perusteella. - Vesi- ja Ympäristöhallituksen Julkaisuja (Sarja A) 177:60-69.

Lindgren, M. 1999: Polypore (Basidiomycetes) species richness and community composition in old-growth boreal forests of northeastern Finland and adjacent
Russian Karelia. 52 pp. - Unpubl. M. Sc. thesis, Department of Ecology and Systematics, Univ. Helsinki.

Niemelä, T. 1997: Suomen kääpien määritysopas.10th ed. - Helsingin Yliop. Kasvit. Monist. 152:1-127.

Niemelä, T., Renvall, P. \& Penttilä, R. 1995: Interactions of fungi at late stages of wood decomposition. Ann. Bot. Fennici 32:141-152.

Penttilä, R. 1994: Kainuun vanhojen metsien kääpälajisto. - Metsähallituksen Luonnonsuojelujulkaisuja (Sarja A) 35:1-63.

Renvall, P., 1992. Basidiomycetes at the timberline in Lapland 4. Postia lateritia n. sp. and its rust-coloured relatives. - Karstenia 32:43-60.

Renvall, P. 1998: Pisan käävät. - Kulumus 13:63-66.

Vehmaa, P. 1999: Etelä-Kuusamon vanhojen metsien kääpälajisto. 63 pp. - Unpubl. M. Sc. thesis, Department of Limnology and Environmental Protection, Univ. Helsinki.

Vesterholt, J. 1997: Rigidoporaceae Jülich. - In: Hansen, L. \& Knudsen, H. (eds.), Nordic macromycetes 3. Heterobasidioid, aphyllophoroid and gastromycetoid basidiomycetes: 169-174. Nordsvamp, Copenhagen.

Yakovlev, E., Scherbakov, A. \& Nikitsky, N. 1995: Records of Coleoptera collected by window traps in the Koitajoki area, Finland in 1993. - In: Hokkanen, T.J. \& Ieshko, E. (eds.), Karelian Biosphere Studies: 167-174. - North Karelian Biosphere Reserve, Joensuu.

Received on 8 April 1999 